\title{
A Way Forward for Discernment in Congregations: LGBTQ+ Inclusion Discernment
}

\author{
Helen Harris *(D), Gaynor Yancey, Kimberly Dawson and Jess Gregory \\ Diana R. Garland School of Social Work, Baylor University, Waco, TX 76706, USA; \\ Gaynor_Yancey@baylor.edu (G.Y.); Kimberly_Dawson@baylor.edu (K.D.); Jess_Gregory2@baylor.edu (J.G.) \\ * Correspondence: Helen_Harris@baylor.edu
}

check for updates

Citation: Harris, Helen, Gaynor Yancey, Kimberly Dawson, and Jess Gregory. 2021. A Way Forward for Discernment in Congregations: LGBTQ+ Inclusion Discernment. Religions 12: 191. https:// doi.org/10.3390/rel12030191

Academic Editor: Edward Foley

Received: 1 March 2021

Accepted: 7 March 2021

Published: 12 March 2021

Publisher's Note: MDPI stays neutral with regard to jurisdictional claims in published maps and institutional affiliations.

Copyright: (c) 2021 by the authors. Licensee MDPI, Basel, Switzerland. This article is an open access article distributed under the terms and conditions of the Creative Commons Attribution (CC BY) license (https:/ / creativecommons.org/licenses/by/ $4.0 /)$.
Abstract: Christian congregations and denominations are increasingly struggling with questions of LGBTQ+ inclusion. The questions of hiring ministers who are LGBTQ+ persons, including LGBTQ+ persons in leadership, and conducting LGBTQ+ marriages are just a few of the discernment discussions that congregations are considering. This article reports on the findings of 97 interviews in 21 congregations reporting on their own discernment conversations. Researchers identified commonalities and differences in groups of congregations with processes that participants saw as instructive. This article is the third in a series of three: common models in the literature, lessons learned from the 97 interviews, and potential processes for congregations considering discernment.

Keywords: LGBTQ+ inclusion; congregations; discernment processes; denominations

\section{Introduction and Literature Review}

Religion is complex. Religions include belief systems, histories, and organizations with organizational power structures, rules, regulations, and structural decision making. Sexual orientation and sexual identity are human concepts that increasingly interact with these cultural and religious beliefs and systems. The interaction of religion and religious beliefs with human sexuality over years in the Christian church has both precipitated and been impacted by shifting value and moral priorities (Baldock 2014; De Jong 2020; Kirkpatrick 2008; McConkey 2018). One has only to consider the marginalization of LGBTQ+ persons in the Christian church in the past 50 years along with the issues of race and the church throughout American history (Tisby 2019; Jones 2020), and one will see that the question of equity and justice in the church is not a new one.

\subsection{History: The Church and Inclusion/Exclusion}

The history of Christianity includes questions of who would belong and be welcomed from the very beginning through current times. Early in Christianity, the question of whether Gentiles could have a place in the group of believers in Jesus as the Christ was debated among those who followed Peter and those who followed Paul. In both cases, those who had historically been excluded were eventually welcomed. In both cases not everyone in the new religion agreed, even as Peter and Paul responded to what they experienced as divine messages for inclusion (Acts 13:44; Acts 10: 9-22). The disciple Phillip encountered an Ethiopian eunuch, someone not welcomed in the Temple for both ethnic and sexual difference. In their conversation, Phillip determined that there was no reason the eunuch could not be baptized and included. In these examples, exclusion changed to inclusion in the process of naming the question and exploring what it would mean to welcome those formerly not welcomed (Garland and Garland 2007).

In recent church history, the question of inclusion of LGBTQ+ persons continues to be broadly debated and is a source of both conflict and generational pain (Fishburn 2003; Gushee 2017; Polaski et al. 2013; Robertson 2017). For centuries, the topic was a hidden one as sexual orientation and identity were not discussed in the church (Baldock 2014; 
Rogers 2009). Sexual sin was variously discussed as fornication, adultery, and divorce although multiple Old Testament narratives show heroes of the faith engaging in these areas (Garland and Garland 2007). The influence of culture on acceptable behavior shows up clearly in the Old and New Testaments. Jesus used stories and parables to illustrate cultural marginalization of others including Samaritans, prostitutes, women with multiple marriages, and those with diseases who were viewed as unclean. In modern history, we learn from the AIDS crisis in the early 1980s in the United States the cultural response to disease associated with sexual behavior in the early naming of AIDS as Gay Related Immune Disorder (GRID) (Shelp and Sunderland 1987). Previously hidden sexual identity and orientation became part of addressing a health crisis. Visibility of this population of persons led to self-advocacy for health care, increased understanding of genetics, and eventually increased advocacy of accepting difference (Baldock 2014). These cultural debates included public policy questions, health equity and public health policy, and related mental health concerns including suicide rates in LGBTQ+ adolescents. Change in the church followed slowly as some Christians became more politically active and some traditionalist Christians became associated with a conservative voting block (Baldock 2014; Dessel 2014).

\subsection{The Church and LGBTQ+ Inclusion}

While there have always been LGBTQ+ persons in the church, the recognition of that in the past several decades is steadily increasing, creating the need for the church to address these brothers and sisters in Christ (Cantorna 2019; De Jong 2020; Cole and Harris 2017). Some conservative denominational groups continue to identify same sex orientation and transsexual identity as issues of sin and promote interventions for change (De Jong 2020; Reamer 2014; Dessel et al. 2017). On the other hand, some denominational groups including Metropolitan Community Church (MCC), Church of Christ, and Affirming Baptist groups, have adopted welcome and affirming positions (Baldock 2014; Polaski et al. 2013). Many others continue to struggle over their responses both denominationally and within individual congregations (Harris and Yancey 2021; Harris et al. 2020). Examples of these include Baptist denominations like the Cooperative Baptist Fellowship whose recent positions attempt to find mid-ground; the United Methodist Church whose past positions have been officially traditional with flexibility for some churches within the denomination making congregational decisions to hire LGBTQ+ ministers and to perform gender inclusion marriages; and the Presbyterian Church USA in which local congregations have both the freedom and the challenging task of deciding their level of inclusion at the congregational level. Finally, conversative and traditionalist denominations, including the Southern Baptist Convention and many Pentecostal denominations, have made organizational decisions and statements that prohibit leadership by LGBTQ+ persons and prohibit gender inclusive marriage. Decisions of congregations for inclusion result in their exclusion from these denominations. As recently as Spring 2021, the Southern Baptist Convention withdrew affiliation from two congregations who were welcoming and affirming (Graham 2021). Notably, in the past several years, the global United Methodist Church (UMC) voted for a more rigorous traditionalist approach which has the denomination poised for likely division (Anderson 2020).

\subsubsection{Examples of Church Discernment Processes}

In the book, Walking the Bridgeless Canyon, Baldock (2014) discusses the history of societal, cultural, and religious responses to what was called "homosexuality" and today is understood professionally as sexual orientation and gender identity. Baldock notes historical, political, and professional shifts in discipline leading both to disagreement and to search for answers in discernment conversations in the 2000s. The early influences of "traveling fundamentalist Methodist preachers in West Texas in the early 1970s" (p. 109) and of one of the earliest recorded sermons on homosexuality preached in Dallas, Texas by W.A. Criswell, "two-time president of the Southern Baptist Convention, and the man 
widely considered the 'father of modern fundamentalism'" on 21 September 1980 in Dallas Texas (p. 110) established the traditionalist position.

Baldock and others identified early history of church discernment since the 1980s and 1990s. Gaede (1998) edited a ground breaking resource addressing both the issue of religion and homosexuality and of civil dialogue on controversial issues. In addition to providing the context of conversations about sexuality, especially in the church, Gaede's authors addressed conversation processes of seven congregations across five denominations. These case examples provide insights on precipitating events, process, response of the community, related social justice issues, denominational implications, making and communicating decisions, lessons learned, and considerations for other congregations.

In 2000, Polaski and Eiland edited a book intended by The Association of Welcoming and Affirming Baptists (AWAB) and American Baptists Concerned (ABConcerned) to support welcoming and affirming congregations and individuals promoting inclusion. As the language and concepts of inclusion and affirmation changed rapidly, a second edition was published in 2013. The stories of congregations and persons provided a collection of "congregational responses to gay and lesbian persons" and "a queer response to congregations" (p. 2). The 2013 revision was the result of responding to changes in the field, increasing congregational conversations, and intentional conversation between the Alliance, the Peace Fellowship, and the Association of Welcoming and Affirming Baptists. This edition includes sections on bible study, theology and spirituality, sciences, sermons, and stories from individuals, families, and congregations. Finally, the editors provide both a bibliography and a study guide for congregations engaging discernment. Similar to Gaede's work, the issues of readiness, difference, and dialogue are central to these congregational stories.

\subsubsection{Issues of Discernment}

The literature includes a number of books in the past 10 years written by pastors and ministers describing their own personal discernment processes and, in some cases, those of their congregations. Chu (2013), Lee $(2012,2018)$, and Vines (2014) are examples of Christians who struggled with their sexuality and their faith and through their own discernment and research resolved that they could be both gay and Christian. Gushee (2017), Wilson (2014), and Wingfield (2019) are examples of ministers and pastors whose discernment processes led them to communicate with their congregations both their findings that Christianity and being LGBTQ+ are compatible and process recommendations for congregational discernment. Collins (2018) describes in his book both his conclusion that it is possible to be welcoming without being affirming as well as a recommended process for congregational discernment. De Jong (2020) proposes a discernment process that is designed to help congregations reconcile conflicts between conservative Christianity, gender identity, and religious liberty.

\section{Materials and Methods}

\subsection{Qualitative Study}

This qualitative, phenomenological study included semi-structured telephone, audio/video, and in-person interviews. The research was exempted/approved by the University's Institutional Review Board (IRB) and has been updated with research assistant changes and every two years per university policy.

The research team included two co-principal investigators, a program manager, and a total of 13 graduate student research assistants over a period of three years. The team decided on churches from three denominational groups for the study: Baptist, Methodist, and Presbyterian, a decision based on including denominations representative of three different denominational organizational structures and responses to the question of LGBTQ+ inclusion. The team goal of a minimum of five congregations in each denomination was achieved in two of the three denominations. The team goal of at least one interview of a 
minister, a lay leader, and a congregant was achieved in all congregations and at least five interviews were completed in 20 of the 21 congregations.

\subsubsection{Sampling}

The sampling strategy was a convenience sample followed by a snowball sample. The team contacted congregations and ministers familiar to the team and requested that those contacts provide additional contacts and possibilities. The criteria for inclusion included affiliation with Baptist, Methodist, or Presbyterian (USA) denominations and either completion of or contemplation of a discernment process around LGBTQ+ inclusion possibilities. The criteria for interviewee inclusion listed adult (1) minister, (2) lay leader, (3) congregant in a congregation selected for the study. The minister who served as the primary contact person with the research team identified and engaged at least one congregational lay leader and at least one congregant familiar with the congregation and the process and, with their permission, provided the research team with their contact information.

\subsubsection{Interviews}

A research team member contacted each potential interviewee including the minister/pastor and provided, by email, both a demographic form for completion and a copy of the IRB approved informed consent. Informed consent was provided verbally at the beginning of each completed interview. At least one interviewee participated in a subsequent clarification interview and interviewees were provided team contact information for member checking and follow-up information. The team developed and used a semi-structured interview tool which provided consistency across the interviews. (Interview questions are found in Appendix A) Interviews were recorded and transcribed by team members and by a transcription service. Interviewers assessed accuracy of the transcription.

Interview transcripts were uploaded into NVivo, a software used widely for qualitative data analysis. Each interview was analyzed in NVivo by at least two team members and often four or more across the several years and teams of research analysis. Team meetings were held every week or two to discuss common findings, identification of themes, and discussion of need for follow-up or clarification. A code book was developed subsequent to the analysis of the first 30 transcripts and amended by the team during subsequent meetings throughout the data analysis.

\section{Results}

The team interviewed 96 persons in 21 congregations: Baptist-12; Methodist-5; Presbyterian-4. One person was interviewed in a follow up interview providing 97 interviews. Eighty-six demographic forms were returned and added to the transcript information for NVivo analysis. The findings of both the qualitative study and the quantitative study included common elements of process and common decisions or outcomes. Those have been reported in a previous article by Harris and Yancey 2021). Themes included: (1) formal and informal conversation; (2) the development of processes rather than the use of existing models; (3) multiple processes in several congregations; the significance of stories of LGBTQ+ congregants; (4) eagerness of participants to share lessons learned and resources (Harris and Yancey 2021; Harris et al. 2021). These findings were consistent, though not universal, across the 21 congregations. Our team continued analyzing the responses of congregants and found that there were some differences in how, when, and why they engaged a process of discernment.

\subsection{Three Groups of Congregations}

There were three clear groupings of congregations among the 21 . In the first grouping, some congregations experienced significant conflict and disagreement. Those for whom the decision was disappointing tended to leave the congregation. The second grouping included congregations which experienced less conflict and more congruence, in some cases 
with a history of previous discernment processes. Finally, other congregations experienced processes led by ministers with a direction to the process. There were, of course, also some combinations of these factors in some groups.

\subsubsection{Congregations with Difficult Processes}

Many of the 21 congregations became aware that they needed to have a discernment conversation even as there were clear divisions in the congregation with strongly held positions for inclusion and strongly held positions for maintaining traditional positions either that LGBTQ+ persons would not be welcomed into leadership or participation in church sacraments, particularly marriage. In these congregations, the conversation was often initiated by one group who felt strongly. Concerns about the differences and that the outcome of a decision would likely result in loss of membership and even a church split contributed to distrust of the process. Those for whom the decision was not acceptable often reported that they did not feel heard or could not support the decision. One participant said: "I think that those that have been on the opposite side-if you want to call it that-did not feel like they were included in the process, fully included in the process and that their voice was not heard ...." (H3B3). Those feelings may have contributed to the decision to leave and the experience of winners and losers, often causing division within the congregation. "It was not surprising because the people who left ... most of the people who left were pretty vocal about it ..." (G2C1).

Our process was very painful ... the realization of what we learned about each other in our approach to this question, in particular, was very painful ...... Those political overtones, though completely unintended by us, you couldn't escape it; it was like this soup that we were living in at that time where ... you're on this side or you're on that side. And that sort of washed over every aspect of your life, and it was horrible (H1B3)

Basically, the church can "come out" in a helpful way and in an unhelpful way. So, for instance, if a church doesn't quite figure out ways to bring everybody along with them, then there can be a schism that takes place .. . Maybe 5-10\% of the congregation left after the decision. And so-the ones that stayed ... were like, "This is the right thing to do" .. but it did cause the congregation and the budget to dip after the decision (G4A1).

\subsubsection{Congregations with History of Process}

A second group of congregations included those that experienced significant trust and respect for different opinions. These congregations often had previous processes in which they identified process elements that worked for them, in some cases with a commitment to other social justice issues, and in other cases, with a commitment to denominational positions with respect to scriptural interpretation and/or political perspectives.

... the church has tackled tough issues before, and so one of the things I think we learned again for multiple times is we can tackle tough issues, we can discuss it, we can disagree, but we can come to a majority decision, and then we can all learn to respect the majority decision and continue to do the important things without letting that separate us (H2B1).

The church has always been-it was, as far as I know, the first Baptist church in our state to have female deacons, ordained women, and allow women into leadership positions in the church. Those guys have crossed that bridge a long time ago. So, the church, throughout its history, has had a-this isn't our first rodeo, so to speak, on a controversial issue (C2B1M).

These churches were identified by participants as being committed to social justice. One participant mentioned: "We're a church that cares a great deal about homelessness and forty percent of all homeless youth are LGBTQ, and so to care about homelessness is to care about this" (C1C1). Others talked about other social justice issues. 
I think the history of this church is they've always been deeply involved in justice issues. So, I think, from what I hear people recalling is, they felt that there was some injustice in place (C3B2J).

It really has been who the church has been all along. They've had very prophetic pastoral leaders. Always pushing issues of justice. So, I think it's, like you said, that's part of the DNA of the congregation (C3A1).

These congregations began with a sense that they already had a congregational identity that focused the conversation on assessing consensus and seeking to find a decision that targeted the identity of the congregation, counted the cost, and modeled commitment.

It's for the Kingdom. We're here to do the work that is laid out before us. It's really these kinds of hard decisions and hard conversations are part of this church and its past. It's not the first time that- there are different issues that this church has made hard decisions when no one else did, and so, it's part of our heritage, really. So, it's very much our DNA (C2A2).

You're gonna lose people. There's no getting around that. You cannot make everyone happy. You have to decide what the highest value is and be okay with that. But you can't stay in the middle. It's not okay. You do more damage in the middle than you do taking a side, honestly (H4A1).

\subsubsection{Ministerial Led Processes}

A third group of congregations included those where the conversation/process was largely generated by the ministerial staff and leadership for whom the decision and direction of the church was clear, who had a clear direction about the decision and the process needed, and for whom managing the process included averting or mediating any potential losses for the congregation. In these cases, the pastoral staff or leadership facilitated the process which helped communicate the strengths and concerns about the decision and how best to live into the church identity already established.

And then there were people who felt that I shouldn't have preached that because I was trying to push the issue versus the congregation sort of-so that was kind of a it totally depends on who you ask if that was a wise sermon or an unwise sermon. I have no regrets about it. But it definitely rattled a few people (C1A1). I did a lot of work, but it didn't end up helping very much. I sort of sat down with everybody individually and I said, "Here's the process our congregation is in the middle of. I can't tell you for sure how it's gonna end up. Here's where I think it might end up. We wanna stay in relationship with you. I just wanna have a conversation with you about what that might look like or if that's possible." So, I tried to be really intentional about being relational with leadership from each of those major entities (C1A1).

We're a healthy, vibrant church. The people who left did not leave talking, in large part I think because they respected me, and they respected the church, and they respected the process (C2A1).

Several United Methodist Churches were led by LGBTQ+ pastors in post denominational decision processes consistent with their decisions to be reconciling. While pastors led the process, these congregations seemed to fit more in the second category of congregations who had in previous processes determined their congregational identity around the issue of inclusion.

Well, I think we still have people who are comfortable with the church and uncomfortable with the denomination because of that. And I think they would be the part of the group I said or those who decided that maybe they didn't agree with the redefinition of marriage but wanted to remain a part of the congregation and a part of the fellowship while disagreeing with what the Book of Order says (G2B1). 
Well, our church we've already said that we're gonna be accepting of anybody and I keep telling my church that the big United Methodist Church is gonna do what they want and this has all been kind of I think distracting us from doing God's work. At least in my church, we are gonna continue to do God's work and we're not gonna get sidetracked by all this drama that the big church is doing, that we have a mission and that mission is to be out and helping make disciples of Jesus Christ and helping the poor and the widows and just doing what the church is actually supposed to be doing. So, as far as our church goes, it hasn't affected it and there's people that are concerned about how the big church is going, but my thing is I'm gonna continue to do Christ's work regardless of what the big United Methodist Church wants to do or is doing (H7A1MH).

\subsubsection{Combination of Processes}

As well as identifying these categories, the team discovered that some congregations included elements of two of the three groups. For example, several included congregations where the congregation held some majority views with consensus which was consistent with the viewpoint of the minister/leadership that defined and led the process. In other cases, the minister/leadership ideology became the path forward to address the divisions within the congregation. Reconciling congregations in the UMC, led by affirming pastors, engaged in processes confirming their previous reconciling positions, a combination of pastoral leadership and consistency with congregational identity.

\subsection{Process Elements for Each of the Three Congregational Groups}

The beginning place, then, for a congregation wrestling with a difficult issue, may well be assessment, i.e., to assess where they fall in this continuum of experiences and perspectives. Are they a congregation facing a divisive issue with strongly held positions on multiple sides? Are they a church with a sense of direction about an issue and a history of trust in similar processes? Are they a church with leadership who have examined an issue have a clear perspective, and are ready to bring the church along with a process that clarifies the issue and the decision? Finally, are they a congregation with a combination of these factors? That assessment can give guidance to the process elements that have the most promise for outcome effectiveness.

One participant said it this way: I think you need a series on how to have healthy disagreements that's not tied to any particular disagreement or practice on a topic that's less emotionally charged for people-or something like that" (C1A1). Another participant included in the church action history the participant's own interpretation that sexual orientation is a choice.

But the Methodist Church decided that they had no place in the Methodist community. At that time, there were several members of the church, I would call them elders of the church, who had children that chose a different sexual orientation than they were born with. And so, this was a very upsetting time for them and it was at this time that the entire congregation pulled together and said we will not accept this. We will be a reconciling congregation. We will accept all people regardless of race, sex, sexual orientation. We just wanted them to be good Christian people or good people. And we set that up. I don't think anyone has ever looked back. There were times we did have-and this was before my time also, so I'm not topic talking from first experiences (H4B1).

\subsubsection{Example 1}

As a church considers a process when there is significant disagreement and/or division in the congregation, one possible approach to mitigate anger and loss is to build into the process more time to establish trust, to give others with different perspectives the space to express those, and for the church to explore and agree on language and definition of terms. Study participants communicated that the length of the process reflected the importance 
of developing conversations and trust; this precludes focusing on a speedy process to a decision.

There are several models for civil conversations that are designed for this kind of trust and communication building but are not intended or designed for decision making. Reflective Structured Dialogue is a method of facilitated conversations developed and used for more than two decades by Essential Partners, a non-profit organization committed to civil conversations that build trust and understanding (Essential Partners 2020; Harris and Yancey 2021). The model began as part of The Public Conversations Project with a goal to cultivate understanding. Facilitators prepare by understanding the questions of the issue, preparing the conversation script and questions, and then functioning as collaborators in facilitating the process; central roles belong to participants while facilitators model the behavior of listening to understand. Dialogue engages a structured process of each participant answering the same question with the same amount of time and an overall goal to hear and be heard and not to problem solve or decide (McCollum 2006). The goal is to listen to understand rather than to develop an argument and to speak to be understood rather than to convince (De Temple and Sarrouf 2017). Questions posed by the facilitator are reflective and require personal rather than theoretical answers: What in your faith explains the bridge builder in you? How does your current perspective on this issue reflect your faith journey (McCollum 2006, p. 13)?

Another model focused on trust building and understanding is Public Deliberation (Shaffer et al. 2017). The Kettering Institute has invested both resources and research in examining the efficacy of this conversation method used in educational and business settings to explore challenging and polarizing topics (National Issues Forums 2020). The method includes providing forums for deliberation beginning with trained facilitators and notetakers, the preparation of identifying key issues, top three approaches for a key issue, and preparing a document for each approach including both actions and trade-offs. Small groups work with a facilitator with 8-10 $\mathrm{min}$ for each approach, providing space to hear one another about both concerns and excitement related to possible actions. This model allows group members with different perspectives to hear from each other about courses of action and share trade-offs, middle ground, or compromises that might increase the possibilities of work together. The premise is ownership. "When people deliberate, they usually rename problems in their own terms. They claim the power inherent in owning their problems" (Mathews 2014, p. 12).

A third dialogue model possibility for congregations seeking to establish relationship and trust as a first step in discernment is Intergroup Dialogue. This model, developed at the University of Michigan by Dr. Adrienne Dessel and team was designed specifically for LGBTQ+ and conservative Christianity conversations, creating "a face-to-face co-facilitated and sustained group experience involving two or more social identity groups who have a history of conflict" (Dessel 2014, p. 317). The process includes support in dealing with emotions and tuning into power differentials while acknowledging a variety of perspectives.

The model includes four stages: (1) coming together and building relationship, (2) exploring commonalities and differences; (3) exploring hot topics; and (4) alliance building and social action planning (Miles et al. 2014, p. 346). The process of dialogue can be introduced over an hour at a conference or over multiple hours across a semester in a university setting.

Doing the work of listening to one another, defining the elements of the discussion and the terminology used, and establishing trust and respect can take months and is worth the investment for those whose starting place in the conversation are very different, perhaps even disagreeable. The development of relationship, trust, common language, and understanding of both motive and willingness to compromise are all investments in working toward a future that can be embraced by those whose capacity for holding in tension multiple points of view has grown. 
These models are not designed to be used for decision making. The work of the congregation begins with developing trust and hearing different perspectives before engaging a process toward decision making. This is designed to reduce conflict and potentially avoid disagreement in the church to maintain relationships including with those for whom the decision of the church does not reflect their perspective.

Once trust and relationships are reinforced through listening, the congregation is ready for the next phase of the process. The second phase of the process for these churches is to identify and implement the elements of their process toward decision making. For the congregations in the study, this phase built on relationships by focusing on gathering information. Common process elements for these congregations in our study included: a study or leadership team; examining sources of information including reading, speakers, and round table discussions; study of scripture and sermon series; and a decision-making method, often a church vote. Participants discussed books that the study team read and/or offered for congregants to read. Some congregations included discussion groups meeting about the content of readings and speakers. Speakers were invited from within and outside of the congregation to speak from their own experiences and/or to speak professionally. Interviewees noted that speakers from multiple perspectives be included, i.e., speakers on both "sides" of the question of inclusion.

\subsubsection{Example 2}

A majority of the participants interviewed were in congregations with processes led by lay leadership study groups, often lasting less than a year and resulting in decisions by vote for being welcoming and affirming or reconciling (UMC) congregations. Frequently, the congregation had engaged in previous processes, not only about the question of LGBTQ+ inclusion, but often about other social issues including racism, civil rights, women in ministry, poverty, and homelessness. The role of the church in responding to injustice and inequity was a common theme for these congregations, and in some cases, especially about LGBTQ+ inclusion. One participant said: "I'd probably say we might lose members if we refuse to talk about it" (G1A1). Another said:

I'm not sure. For that specific reason-I mean, because the church has a number of different social justice stances, and it might be all wrapped up in that, why people are attending. But I mean, just an estimate, maybe five to 10 people that have come. I mean, if I count all the LGBT members of our church, for sure, all of them, so that actually probably would push it beyond 10, once you gather together allies and members of the community, that would come in to stay for that reason $(\mathrm{C} 3 \mathrm{~B} 3 \mathrm{M})$.

The role of the congregation in the community made a difference as well:

And I think a little history about our church might be important. For years, our church provided the meeting place for PFLAG ... And it had always been a very open and accepting body regardless of someone's sexual orientation. Nobody really knew—or if they knew, they didn't really care what someone's orientation was-and none of that changed (G2B1).

While losses of some members subsequent to the decision were not unusual in these congregations, the perspective of participants was often that there were equivalent gains in members, increased diversity in the congregation, and congruence with the identity of the church (Harris et al. 2021).

We did lose a few families. Interestingly, not very many people would say they left because of that. I think most people would say they left because of me. At least, that's been my experience. I kind of interpret that as I'm an easier target. $I^{\prime} m$ the new pastor. It's easier to be upset with me. But-you know (C1A1).

So, we've had people who've left. We've had people who've come ... but there has been concern that some of the people who left either because of the LGBTQ 
issue or for some other reasons that may have been connected in some ways to that (C1B1).

Consistent process elements in these congregations were study group leadership, reading and discussion groups, guest speakers largely from within the congregation, and round table or other interactive discussions in which members could express their concerns, questions, and perspectives. Resources often cited by participants are available at the Center for Church and Community Impact at the Garland School of Social Work at Baylor University.

\subsubsection{Example 3}

Several congregations included participants who described processes led formally or informally by the pastor or pastoral staff. In several cases, the pastors who led the process wrote books defining the process, the decision, and the rationale for the decision. The decision was consistent with the pastor's position on LGBTQ+ inclusion as evidenced in their interview.

Several participants from UMC congregations noted that their church had made an informal decision already to be a reconciling church. The conference vote of the UMC global was strongly traditionalist and prompted these congregations to revisit the conversation to determine next steps. As the congregations/participants were concerned about their affiliation with the UMC and if leaving would mean losing their buildings and/or their finances, the decision to remain reconciling seemed a foregone conclusion. The question of losses was less about membership and more about denominational regulations specific to ownership of the building and grounds and the congregation's offerings.

I don't think it's exactly excommunication, but you know you get kicked out of the church. And so based on what the United Methodist Church has said formally as a church body, those things could potentially happen. I mean I doubt that they would happen because of the scale that they would have to discipline everyone who's in support of reconciliation is huge. But also the bishop of our jurisdiction, she is also an open lesbian and so in addition to receiving death threats the whole time she's been bishop, she now has to face losing her ordination because these are really serious ... Well, not to mention the fact that it's very hard to convince people in the queer community that we are inclusive and affirming when our own church body is saying that we are not. So, we go to gay Pride or we go to gay events (M4B3M).

In these cases, the process seemed about formalizing a decision that was both consistent with the vision of the pastor and leadership and consistent with the church identity as understood both by leadership and congregants. The process mattered for establishing the position of the church but was not about making a decision that was uncertain and fraught with conflict.

For those congregations with a combination of these factors, tailoring their process to the factors should address the building of relationship and trust, maximizing the identity established by previous processes, and/or benefitting from the leadership direction and guidance. This would be an important area of additional research in the future for churches that fall in this category.

\section{Discussion}

The topic of LGBTQ+ inclusion in congregations and denominations has not been an easy topic for most. Disagreement over privilege and power has never been easy in culture or in the church. From the beginning that has been the case as new religions, or ideals within an existing religion, challenged the existing power and belief structures. Jesus established precedent for the church and counter-cultural relationships as Jesus complimented the good Samaritan; befriended divorced, single, and marginalized women; touched outcast lepers; and even invited children to come to him over the admonitions 
of others (Garland and Garland 2007). These examples highlighted the challenge of the new faith called the Way (Acts 24:14 NIV). They also illustrate the potential for not only civility in the church but for relationships that embrace difference. While LGBTQ+ persons have been present but hidden in the church and in society for centuries, the possibilities for extending care to one another, even in the face of different understandings of scripture or doctrine are evident in the successful processes of congregations across these three denominations.

In the United States, the AIDS epidemic forced the LGBTQ+ population into the health care system as they were stigmatized and blamed for the disease which was first named Gay Related Immune Deficiency (GRID) (Baldock 2014). Over time, a few denominational groups responded with love and acceptance. That was not true of the majority of congregations and denominations, particularly conservative theological groups for whom same sex orientation or attraction was identified as sin that marginalized LGBTQ+ persons. However, in the past 20 years, denominations and congregations have increasingly engaged in public policy, politics, and in some cases, culture war. LGBTQ+ Christians have begun to come out, and speak out, leading to congregations and denominations needing to address systemic responses to them. Congregations and denominations have been forced, in some cases by public policy and in other cases by denominational decisions, to grapple with the congregation's response to LGBTQ+ persons among them. Some entire denominations have adopted inclusive, affirming, and reconciling policy and practices. Examples include the Church of Christ and Alliance of Baptists. Others continue to discuss and, in many cases, disagree and, in some cases, split as an answer to the disagreement (Baldock 2014). There are lessons in the experiences of these congregations and denominations that can inform the processes of congregations engaging in discernment conversations in the future. The primary reported concern of the congregations in this study was fear of losses of relationships, members, finances, and denominational affiliation (Harris et al. 2020; Harris and Yancey 2021). While these findings and possibilities do not address the potential loss of denominational affiliation, they do address relationships and the potential for loss of members and with members, finances.

Congregations continue to struggle with the polarized discussions about acceptance and rejection of persons who experience sexual differences. These are concerns and differences in families and in families of faith where relationships are strained and sometimes broken. That brokenness has extended to congregations separated from their denominations. It has also provided opportunity for congregations to examine who they are and who they want to be.

Then the United Methodist Church had this terrible vote and kind of went back into history in terms of openness and equality and a lot of the ... So, I was on church council at the time. A lot of the leaders were really frustrated about it. A lot of people like me-even lifelong Methodists like myself-were like, "I have to leave the church. How can I sit here and be complacent?" So, out of that kind of people talking about it, the church council decided to move forward with the reconciling process a second time- or at least a second time since I've been a member of the church. So, I want to say the spring-late spring maybe-we started this process again and so people volunteered to be on the reconciling ministry steering committee (M7B3V).

\subsection{Strengths and Limitations}

The qualitative study includes 97 interviews, producing a substantive collection of data from ministers, church leaders, and congregants in three Protestant denominations with different administrative structures and somewhat disparate histories with respect to LGBTQ+ inclusion. The large sample and substantive data allowed the researchers to analyze it with multiple approaches. The NVivo analysis by multiple team members over several years provided a diversity of perspectives and team examination of common themes and trends across denominations and congregations. The team's findings that outcomes 
were influenced by leadership, by decision making processes, and most importantly by the combination of where the congregation or denomination began and who they saw themselves being at the end of the process. One limitation, related to the strength of the numbers and perspectives, is the convenience sampling method, i.e., the team's awareness of Baptist, Methodist, and Presbyterian congregations who had had or were considering discernment conversations and were willing to participate in the research. In a snowball sampling strategy, participants from those congregations then referred the team to other congregations who had had or were considering discernment processes. The sample then included congregations that had considered the question of discernment and what that might mean for them. This likely influenced the categories of congregations identified by the team. Qualitative study results are not, by definition, generalizable, but this limitation is an important one in considering the possible skewing of the typing of congregations in the study.

A second limitation in the study is the higher percentage of congregations from Baptist denominations, particularly those either members of or former members of the Southern Baptist Convention, the Baptist General Convention of Texas, and/or the Cooperative Baptist Fellowship. Additionally, the team was only able to secure five Methodist congregations and four Presbyterian congregations. This was a function of the convenience sample and the large concentration of Baptists on the research team. Finally, limiting the study to three denominations leaves several other denominational approaches to the question of LGBTQ+ inclusion unexamined.

Strengths of the Study

One significant strength of the study was the large research team with three or more new research assistants each of the three years. This multi-year look at the data by teams of researchers allowed fresh eyes to examine the data and decisions around coding of themes.

The use of NVivo software, designed to provide multi-level analysis, was also a significant strength. The teams were able to free code and to use coding programs in the NVivo software to identify trends in the data. The research teams met at least monthly and frequently met weekly to discuss emerging themes, understandings of the data, language and terms in the emerging literature, and addressed any bias identified in the team. Over a three-year period, the team read and annotated more than 90 resources specific to LGBTQ+ discernment and congregations. Further, members of the team had contact with leaders and participants from many of the congregations with opportunity to check in about findings and about ongoing changes and developments in congregations and denominations over time.

\subsection{Significance of the Study}

Congregations who had engaged in discernment processes were most receptive to participating in the study. Even when the congregation had experienced some loss of membership and loss of affiliation with a denominational body, the participants noted that the process was important to their growth and identity and that the ultimate result of the decision was gain of members and affiliation with a denomination whose values were consistent with the majority of church members. Further, participants commented on the importance of honoring their commitment to social justice, to the gospel message that all are welcome at Christ's table, and the inclusion of gay children/adults who had grown up in the church. Rather than an admonition to other congregations to make the same decision as many of the congregations, the overwhelming message of participants was to have the conversation regardless of the decision made by the congregation. Participants reported that the discernment process brought conversations into the open, offered safe spaces for discussion, and made apparent a question that had been simmering under the surface for years.

Participants from each category of congregations identified here acknowledged that while the process was painful, the discussions were both necessary and freeing. The 
importance of hearing the stories and life experiences of gay persons in the congregation was highlighted by many participants. In some cases, participants knew the identity of some of the persons in the congregation who were gay or transgender. In other cases, they reported being glad to know so that congregants did not have to hide who they were or pretend. Participants found that openness to be freeing for straight congregants as well as gay congregants and in some ways, evidence of grace.

\section{Conclusions}

For congregations dealing with the question of LGBTQ+ inclusion and considering a discernment process, the lessons learned from 97 interviews of ministers, lay leaders, and congregants who have considered or had their own congregational processes provide strong lessons learned and resources available. The interviews across 21 congregations provide a range of experiences with process from pre-process through the discernment process and beyond to post-process impacts. Participants provide insights around process elements that were effective and those that led to more challenges. Further, the data from interviews provided researchers with insights about the congregation prior to the discernment process suggesting considerations important to other congregations exploring their options and providing hope for those congregations interested in discerning their truth, whatever that is. One participant said: "It was at this time that the entire congregation pulled together and said we will not accept this. We will be a reconciling congregation. We will accept all people regardless of race, sex, sexual orientation" (H4B1).

\subsection{Preparation}

The importance of assessment and preparation was a common theme.

It was about, "Who are we as a congregation and how do we be God's people?" So, I think being very clear about why you're having the conversation and making sure that your motives are right, that they're theologically grounded and it's not about money or members or you know any of those other things ... So, I think that would be kind of key is making sure you know what your "why" is before you ever start" (G6B1MH).

Further, be prepared for a longer process of relationship building when needed.

Well, I would say do it on purpose. Decide who you want to be. Understand that there can be consequences to being open and affirming. Plan carefully. Be open. Don't hide things. Don't whisper in the corners. Be open to everybody but just be ready that there will be some people who won't be accepting of it. You cannot change people overnight and long-held beliefs, you just can't tell people to get over it. It doesn't work that way. So, be patient, be prayerful, be kind, be thoughtful, and be ready (G4B1).

The overarching lesson, repeated by many participants, was to have the conversation or discernment process and not be dissuaded by fears of disagreement, conflict, or losses of members. As one participant shared: "“Listen. Listen to the people on the other side and let them know you're listening and let them know ... regardless of which way it goes, we are one" (M2B2M).

I think the biggest things other congregations could take away from this would be like A. just have the discussion. It needs to be had. There some churches that aren't ready to have it like that like they know that it would be super contentious if they had the discussion so they're waiting but I would say every church should at least have it no matter where they end up on it they should have the discussion and then have it be whatever it is (G1B1).

Even when congregations experienced conflict and/or loss, those interviewed found in a significant majority of responses that the conflict was already there and needed to be addressed. 
... I think overall the church has learned how to have more respectful conversations about difficult topics and things we disagree about ... . I think the church has learned how to talk about things and to be more open to other people's point of views and also realize that there's a lot of differing point of views about a whole slew of things, including the bible and all of that (M7B3V).

I'm looking at churches, organizations, people helping churches and congregations get through the process in a healthy way is not only something that's good for the LGBTQ community and inclusion, but also good for many other very divisive topics within congregational life. And so I think that's needed more and more (G4A1).

\subsubsection{Hear Every Voice}

Other variables seemed important as to how the process was managed and turned out. Participants described the importance of feeling and being heard; when they felt that their perspective mattered and was respected, there appeared to be more possibility of staying in the face of a decision that was different than they wanted or would have chosen.

I would say giving every voice a chance to be heard ... and even to the point of saying, "We would really like to hear from everyone" knowing some people are more reluctant to speak up ... So, I think that was just a big lesson learnedreally hearing from everyone, really trying to just be as clear and say things head-on so that people know exactly what the choice points are (C3A2MH).

\subsubsection{Leadership, Process, and People Matter}

The three elements which influenced each other were leadership in the process, the elements of the process, and the people of the congregation. Most congregations used processes that included a leadership team or a study team that included ministers and lay leaders from the congregation. That team generally read resources, scheduled speakers, facilitated conversations, examined options, decided on a decision method (often a vote), and communicated the decision through sermons, church newsletters, meetings, and the website. While the elements of the process were important, the most significant component of every process was keeping the people at the center of the process. As one participant said:

Whether preparation is done by the ministerial staff, lay leadership like deacons or elders, or another church entity, the leadership model for choosing and implementing the process is as important as the process itself. That includes understanding the church identity and church goals, how hierarchical the leadership model is, and how decisions are made in the congregation. In every process and every decision, the people of the congregation matter and should be considered with care. And I think that's the best advice I can give any institution that's considering is never lose sight in whatever process that's that congregational polity, to always make people the most important thing (G4A2).

It was clear as well that there is no perfect model or process and no decision that is right for every congregation.

Of course, every church is going have to come to their own decision, while we feel strongly that our outcome was where God was leading us ... I would respect if they studied and prayerfully approached the Christian and came to a different conclusion, our story has a bit of a problem with churches that just won't even face the question. But that's not my place to say. It just seems a little, burying your head in the sand to say it's not a question that deserves attention, and that these people deserve thoughtful, prayerful consideration. But I think choose the process that's right for your congregation knowing that people are going to criticize your process because people find it easier to say it was a bad process than to admit that they came to a different decision (H1B3). 
Lastly, participants expressed that it is important to remember that this is about human beings, people who are impacted by life events and about decisions that we make.

So, what I wish I knew I mean that people aren't an issue that these are people's lives and it's easy for us to have conversations about the issue and how it affects our churches and denominations and schools and all of the above but-at the end of the day - these are people who are beloved children of God (H5A1).

These participants in congregations with discernment histories identified importance, motivation, commitment, and impact of the investment of their congregations in considering the question of LGBTQ+ inclusion in the church. In some cases, that meant losses and gains of congregants and losses and gains of denominations. In every case, it meant clarifying who they are and who they intend to be as a family of faith.

Author Contributions: H.H. provided conceptualization, literature review/resources, methodology, funding acquisition, investigation, data analysis, writing original draft preparation, and project administration. G.Y. provided conceptualization, methodology, funding acquisition, validation, investigation, analysis, project administration, and writing review and editing. K.D. provided literature review/resources, data analysis, validation, and editing. J.G. provided literature review/resources, data analysis, validation, and editing. All authors have read and agreed to the published version of the manuscript.

Funding: This research was funded by the Baugh Foundation.

Institutional Review Board Statement: This research was reviewed by The Baylor University Institutional Review Board, Reference number 1247934 and found to be exempt according to federal regulation 45 CFR 46.101(b). The study was conducted according to the guidelines of the Declaration of Helsinki, and approved by the Institutional Review Board of Baylor University in May 2018 and obtained continued exemption approval in May 2020, Reference number 1247934 and found to be exempt according to federal regulation 45 CFR 46.101(b).

Informed Consent Statement: Informed consent was obtained from all subjects involved in the study.

Data Availability Statement: The data presented in this study are available on request from the corresponding author. The data are not publicly available due to the privacy of congregations and participants which might be identified by those knowledgeable about the congregations.

Acknowledgments: Support for this article was provided by Carolyn Cole, researcher, Mallory Herridge, project manager, and Geneece Goertzen, research assistant. Thank you to the graduate student assistants over several years who participated in literature review and data collection.

Conflicts of Interest: The authors declare no conflict of interest. The funders had no role in the design of the study; in the collection, analyses, or interpretation of data; in the writing of the manuscript, or in the decision to publish the results.

\section{Appendix A}

Congregational Discernment Research Study

Qualitative Interview Questions

(Questions may include follow up questions not on this list during the interview or later after the interview)

The Researcher will provide overview of the research including the role of the interview and the plan to record, transcribe and de-identify the interview.

Discuss and secure informed consent with reminder that the participant may withdraw from the research at any point in the process including during the interview.

Interview Questions:

- Before we begin, do you have any questions for me about the consent or the process?

- Please provide basis demographic about yourself: Age; Marital Status; Race/Ethnicity; Religious affiliation; Educational preparation/seminary?; Marital Status; If married, how long; Children; Grandchildren; church membership in this church including how long; leadership roles in the church; other information you would like for us to 
know ... This information will be separated from the interview in a demographics document connected only to your interview ID number.

- How would you describe your congregation?

- What challenges have you seen your church work through? What has the church learned from these experiences?

- What is the congregations' position with respect to having a conversation about LGBTQ + persons in the congregation? Are you: considering a conversation? Having a conversation? Had a conversation?

- What vocabulary is used in your congregation? Congregation/church/fellowship? Church members? Pastor/minister/priest/?; LBGTQ+?

- What is the leadership format in your church? Elders? Deacons? Coordinating Council? What type of church governance is in place?

- What was your congregation's process for discernment in the conversation related to more open membership?

- Who led it? (members, deacons, discernment committee, pastoral team?)

- Was there a precipitating event(s) that led to the discussion?

- What was the process for planning the discussion?

- How would you describe the health or climate of the congregation before the church discussions?

- Who led the plan? Process for deciding on leadership?

- Discuss the process and who was included.

- What went well?

- What did not go well?

- What do you wish your church had done differently?

- Did discussion include conversation about LGBTQ+ youth? Depression, anxiety, suicide?

- How would you describe the health or climate of the congregation after the discussions? After the decision? Now?

- What recommendations do you have for other congregations interested in engaging in a similar process of discernment?

- What was the conclusion of the process?

- How was it arrived at?

- How, and to whom, was it communicated?

- What have been the intended and unintended consequences of the decision/ conclusion of the process?

- Once the decision was made, discuss any denominational impacts or repercussions (including affiliation, budget, etc.).

- Discuss impact on church membership, attendance, leadership, diversity, neighborhood, budget, immediately and over time?

- What are the lessons learned from the process and from the conclusion?

- What do you wish you had known as you started down the process of discernment?

- What resources do you believe are important in assisting congregations once they have made their decision to be an accepting congregation?

- What else would you like to share with us about this process and your congregation?

- What else would you like to share with us about this process and yourself and your family?

These questions will be reviewed and modified as needed after the first set of 8-10 interviews. Modifications may be made as needed in individual interviews to address follow up questions. 


\section{References}

Anderson, Meg. 2020. United Methodist Church Announces Proposal to Split over Gay Marriage. Available online: https://www.npr. org/2020/01/04/793614135/united-methodist-church-announces-proposal-to-split-over-gay-marriage (accessed on 22 February 2021).

Baldock, Kathy. 2014. Walking the Bridgeless Canyon: Repairing the Breach between the Church and the LGBT Community. Reno: Canyonwalker Press.

Cantorna, Amber. 2019. Unashamed: A Coming-Out Guide for LGBTQ Christians. Nashville: Westminster John Knox Press.

Chu, Jeff. 2013. Does Jesus Really Love Me: A Gay Christian's Pilgrimage in Search of God in America. New York: Harper Perennial.

Cole, Carolyn, and Helen Wilson Harris. 2017. The lived experiences of people who identify as LGBT Christians. Social Work $\mathcal{E}$ Christianity 44: 31-52.

Collins, Travis. 2018. What Does It Mean to Be Welcoming? Navigating LGBT Questions in Your Church. Westmont: InterVarsity Press.

De Jong, Dirk H. 2020. Conservative Christianity, Gender Identity, and Religious Liberty: A Primer and a Proposal. London: Palgrave Macmillan.

De Temple, Jill, and John Sarrouf. 2017. Disruption, dialogue, and swerve: Reflective structured dialogue in religious studies classrooms. Teaching Theology and Religion 20: 283-92. [CrossRef]

Dessel, Adrienne B. 2014. Bridging the conservative Christianity and sexual orientation divide: A review of Intergroup Dialogue pedagogy and practice. In Conservative Christian Beliefs and Sexual Orientation in Social Work. Edited by Adrienne Dessel and Rebecca Bolen. Alexandria: CSWE, pp. 313-44.

Dessel, Adrienne B., Jeanna Jacobsen, Denise L. Levy, David McCarty-Caplan, Terrence O. Lewis, and Laura E. Kaplan. 2017. LGBTQ Topics and Christianity in Social Work: Tackling the Tough Questions. Social Work and Christianity 44: 11-30.

Essential Partners. 2020. Race in America: A Dialogue Guide from Essential Partners. Cambridge: Essential Partners.

Fishburn, Janet F. 2003. People of a Compassionate God: Creating Welcoming Congregations. Nashville: Abingdon Press.

Gaede, Beth Ann, ed. 1998. Congregations Talking about Homosexuality: Dialogue on a Difficult Issue. Bethesda: Alban Institute Publications.

Garland, David E., and Diana R. Garland. 2007. Flawed Families of the Bible: How God's Grace Works through Imperfect Relationships. Grand Rapids: Brazos Press.

Graham, Ruth. 2021. Southern Baptists Expect 2 Churches Over Sex Abuse and 2 for L.G.B.T.Q. Inclusion. New York Times. February 23. Available online: https://www.nytimes.com/2021/02/23/us/southern-baptist-convention-expels-churches.html (accessed on 24 February 2021).

Gushee, David P. 2017. Changing Our Mind. Canton: Read the Spirits Books.

Harris, Helen, and Gaynor I. Yancey. 2021. The why and how of congregational discernment in LGBTQ+ inclusion: Models in the literature. Religions 12: 14. [CrossRef]

Harris, Helen, Gaynor Yancey, Veronica L. Timbers, and Carolyn Cole. 2020. LGBTQ+ and Christian? Who Decides? Journal of Religion $\mathcal{E}$ Spirituality in Social Work: Social Thought 39: 452-73.

Harris, Helen, Gaynor I. Yancey, Kimberly Dawson, and Jess Gregory. 2021. Congregational discernment in LGBTQ+ inclusion: Process lessons from 21 congregations. Religions 12: 25. [CrossRef]

Jones, Robert. 2020. White Too Long. New York: Simon \& Schuster.

Kirkpatrick, Frank G. 2008. The Episcopal Church in Crisis: How Sex, the Bible, and Authority Are Dividing the Faithful. Westport: Praeger Press.

Lee, Justin. 2012. Torn: Rescuing the Gospel from the Gays-vs.-Christians Debate. New York: Jericho Books.

Lee, Justin. 2018. Talking across the Divide: How to Communicate with People You Disagree with and Maybe Even Change the World. New York: TacherPerigee.

Mathews, David. 2014. Ships passing in the night. Journal of higher Education Outreach and Engagement 13: 5-16.

McCollum, Marlis. 2006. Respectfully Disagreeing: How Dialogue Works to Transform Conflict. Congregations Magazine 32: 10-15.

McConkey, Dale. 2018. United Methodists Divided: Understanding Our Differences over Homosexuality. Washington, DC: Global Parish Press.

Miles, Joseph R., Christine L. Henrichs-Beck, and Jon R. Bourn. 2014. Intergroup Dialogue: A Method for Engaging Students around Religion and Sexual Orientation. In Conservative Christian Beliefs and Sexual Orientation in Social Work. Edited by Adrienne Dessel and Rebecca Bolen. Alexandria: CSWE, pp. 345-76.

National Issues Forums. 2020. Back to Work: How Should We Rebuild Our Economy? Dayton: Kettering Foundation, ISBN 978-1-94620664-0.

Polaski, LeDayne McLeese, Millard Eiland, and Cody J. Sanders. 2013. Rightly Dividing the Word of Truth: A Resource for Congregations on Sexual Orientation and Gender Identity. Charlotte: Baptist Place Fellowship of North America.

Reamer, Frederic G. 2014. Ethical Issues and Challenges: Managing Moral Dilemmas. In Conservative Christian Beliefs and Sexual Orientation in Social Work: Privilege, Oppression, and the Pursuit of Human Rights. Edited by Adrienne B. Bessel and Rebecca M. Bolen. Alexandria: CSWE Press.

Robertson, Brandan. 2017. Our Witness: The Unheard Stories of LGBT+Christians. London: Darton, Longman + Todd.

Rogers, Jack. 2009. Jesus, the Bible, and Homosexuality: Explode the Myths, Heal the Church, Revised 1st ed. Louisville: Wesminster John Know Press. 
Shaffer, Timothy J., Nicholas V. Longo, Idit Manosevitch, and Maxine S. Thomas, eds. 2017. Deliberative Pedagogy: Teaching and Learning for Democratic Engagement. East Lancing: Michigan State University Press.

Shelp, Earl E., and Ronald H. Sunderland. 1987. AIDS and the Church. Philadelphia: The Westminster Press.

Tisby, Jemar. 2019. The Color of Compromise. Grand Rapids: Zondervan Books.

Vines, Matthew. 2014. God and the Gay Christian. Grand Rapids: Zondervan.

Wilson, Ken. 2014. A Letter to My Congregation: An Evangelical Pastor's Path to Embracing People Who Are Gay, Lesbian and Transgender into the Company of Jesus. Canton: Read the Spirit Books.

Wingfield, Mark. 2019. Why Churches Need to Talk about Sexuality: Lessons Learned from Hard Conversations about Sex, Gender, Identity, and the Bible. Minneapolis: Fortress. 